\title{
Response of Rabi Sorghum Genotypes (Sorghum bicolor (L) Moench) to Different Fertility Levels under Rainfed Conditions
}

\author{
V.S. Kubsad* \\ University of Agricultural Sciences, Dharwad, Karnataka 250 005, India \\ *Corresponding author
}

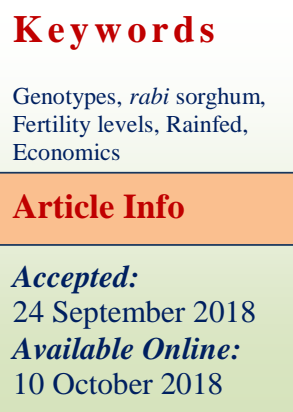

\section{Introduction}

Sorghum (Sorghum bicolor (L) Moench) is an important grain and fodder crop of rainfed and or dry land areas, providing food for human beings, fodder for cattle and feed for birds. It is regarded as 'King of millets' and stands in $\mathrm{IV}^{\text {th }}$ position in staple food crops after rice, wheat and maize. In Karnataka, the area under rabi sorghum is more than kharif sorghum which is mainly due to its preference as sources of food and fodder particularly is North Karnataka. It is grown over an area of 9.99 lakh hectares with a production and productivity of 8.36 lakh tones and $837 \mathrm{~kg} / \mathrm{ha}$ respectively (Anon, 2015). Sorghum responds
A field experiment was conducted to study the response of rabi sorghum genotypes (Sorghum bicolor (L) Moench) to different fertility levels under rainfed conditions at AICRP on Sorghum, Main Agricultural Research Station, Dharwad (Karnataka) during abi, 2017. The experiment was laid out in split plot design with twenty four treatment plots and three fertility levels in sub plots. Application of $100 \%$ RDF recorded significantly higher plant height $(175.0 \mathrm{~cm}), 100$-seed weight $(3.94 \mathrm{~g})$, ear weight $(95.8 \mathrm{~g})$, grain yield/plant $(49.5 \mathrm{~g})$, grain yield $(50.2 \mathrm{q} / \mathrm{ha})$, fodder yield $(7.83 \mathrm{t} / \mathrm{ha})$, gross returns (Rs. 1,11,468/ha), net returns (Rs. 76,413/ha) and B: C ratio (3.18) compared to other fertility levels. Both the test hybrids, SPH-1835 and SPH-1836 produced higher grain yield compared to check hybrids (CSH-13R and CSH-15R). Test variety SPV-2405 also recorded higher grain yield $(50.4 \mathrm{q} / \mathrm{ha})$, fodder yield $(8.07 \mathrm{t} / \mathrm{ha})$ and net returns (Rs. $78,238 /$ ha) compared to test variety (SPV-2348) and check variety (CSV-29R).

well to the applied inputs. The yield potential of any crop in general and sorghum in particular can be exploited only under favorable production management practices viz, recommended doze of fertilizer, irrigation, weeding, plant protection etc.

Among these production factors, fertilizer plays a vital role in deciding the yield of sorghum. The nutrient requirement further increases with the use of high yielding cultivars and also soil moisture availability. The newly released varieties and hybrids respond differently to different fertility levels depending upon the type of root system and their root density. Hence, there is need to 
optimize the fertilizer quantity required to obtain highest productivity (Tandon and Narayan, 1990).

Therefore the present investigation is planned to study the response of rabi sorghum genotypes to different fertility levels.

\section{Materials and Methods}

The experiment was conducted on medium deep black soil at Main Agricultural Research Station, University of Agricultural Sciences, Dharwad (Karnataka) during rabi, 2017 under rainfed condition. The soil of the experimental site had pH 7.2 medium organic carbon $(0.59$ $\%)$, low available $\mathrm{N}$ (247 $\left.\mathrm{kg} \mathrm{ha}^{-1}\right)$, low available $\mathrm{P}_{2} \mathrm{O}_{5}\left(17.33 \mathrm{~kg} \mathrm{ha}^{-1}\right)$ and high available $\mathrm{K}_{2} \mathrm{O}$ (403 kg ha-1). The experiment was laid out in split plot design with twenty four treatment combinations and three replications. The treatments consisted of eight genotypes (SPH-1835, SPH-1836, SPV-2348, SPV-2405, CSH-13R, CSH-15R, CSV-22R and CSV-29R) as main plots and three fertility levels (50\% RDF, 75\% RDF and 100\% RDF (a) 50:25 kg N and $\mathrm{P}_{2} \mathrm{O}_{5} / \mathrm{ha}$ ) as sub plots. All the sorghum genotypes were sown on $24^{\text {th }}$ September, 2017 at the spacing of $45 \times 15$ $\mathrm{cm}$. The different fertility levels as per the treatments in the form of urea, single super phosphate and muriate of potash were applied to crop at sowing. The crop was raised by following the recommended practices. The total rainfall received during the cropping period was $287.0 \mathrm{~mm}$ in 21 rainy days and the crop growth and expression was satisfactory. The Furadon granules @ 12 kg/ha were applied to whorls of crop followed by Cymbush (10 EC) spraying @ 10 ml/16 liters of water to control shoot fly and stem borer. The crop was harvested on $15^{\text {th }}$ February, 2018. The various growth and yield parameters (Radford, 1967) and yield were calculated as per the standard procedure. The data collected on different parameters were subjected to statistical analysis as described by Gomez and Gomez (1984) for better interpretation of results.

\section{Results and Discussion}

\section{Fertility levels}

The data presented in Table 1 revealed the linear increase in yield parameters, grain and fodder yield and also gross returns, net returns and B: C ratio. Application of $100 \%$ RDF recorded significantly higher grain $(50.2 \mathrm{q} / \mathrm{ha})$ and fodder yield (7.83 t/ha) over $50 \%$ RDF and it was on par with $75 \%$ RDF. The increase in grain and fodder yield was to an extent of $11.1,4.8 \%$ and $12.1,9.1 \%$ higher over $50 \%$ and $75 \%$ RDF respectively. Significant improvement in higher grain and fodder yield could be attributed to profound influence of $\mathrm{N}$ and $\mathrm{P}$ fertilization on vegetative and reproductive growth of the crop due to increase in nutrient accumulation and their translocation to sink. Similar results were reported by Singh et al., (2005) in sorghum. The higher grain yield at $100 \%$ RDF can be related to higher values of yield parameters viz., 100-seed weight (3.94 g), ear weight (95.8 g/plant) and grain yield /plant (49.5 g). The better performance of these yield parameters may be attributed to mineral nutrition especially nitrogen which plays an important regulative functional role in plant system through synthesis and translocation of growth hormones which help in better growth and development of plant (Bringer at al., 1980). Further, the same treatment realized the maximum gross returns, net returns and $\mathrm{B}$ : $\mathrm{C}$ ratio compared to 75 and 50\% RDF (Mali at al., 2000).

\section{Genotypes}

In the experiment, both varieties and hybrids were evaluated and compared with checks (Table 1). 
Int.J.Curr.Microbiol.App.Sci (2018) 7(10): 3282-3286

Table.1 Growth and yield of advanced rabi sorghum genotypes as influenced by fertility levels

\begin{tabular}{|c|c|c|c|c|c|c|c|c|c|c|}
\hline Treatments & $\begin{array}{c}\text { Plant } \\
\text { height } \\
(\mathrm{cm})\end{array}$ & $\begin{array}{c}\text { 100- } \\
\text { Seed } \\
\text { weight } \\
\text { (g) }\end{array}$ & $\begin{array}{c}\text { Ear } \\
\text { weight } \\
\text { (g/ } \\
\text { plant) }\end{array}$ & $\begin{array}{c}\text { Grain } \\
\text { yield / } \\
\text { plant } \\
\text { (g) }\end{array}$ & $\begin{array}{l}\text { Grain } \\
\text { yield } \\
\text { (q/ha) }\end{array}$ & $\begin{array}{l}\text { Fodder } \\
\text { yield } \\
\text { (t/ha) }\end{array}$ & $\begin{array}{l}\mathbf{H i} \\
(\%)\end{array}$ & $\begin{array}{c}\text { Gross } \\
\text { returns } \\
\text { (Rs/ha) }\end{array}$ & $\begin{array}{c}\text { Net } \\
\text { returns } \\
\text { (Rs/ha) }\end{array}$ & $\begin{array}{l}\text { B: } \\
\text { C }\end{array}$ \\
\hline \multicolumn{11}{|c|}{ Fertility levels : } \\
\hline $\begin{array}{l}1.50 \% \\
\text { RDF }\end{array}$ & 166.6 & 3.57 & 79.6 & 43.2 & 44.6 & 6.88 & 41.4 & 106706 & 71658 & 3.04 \\
\hline $\begin{array}{l}2.75 \% \\
\text { RDF }\end{array}$ & 171.2 & 3.72 & 86.7 & 47.6 & $47.8^{\prime}$ & 7.12 & 40.8 & 107924 & 72873 & 3.08 \\
\hline $\begin{array}{l}3.100 \% \\
\text { RDF }\end{array}$ & 175.0 & 3.94 & 95.8 & 49.5 & 50.2 & 7.83 & 38.7 & 111468 & 76413 & 3.18 \\
\hline S.Em+ & 1.1 & 0.035 & 2.1 & 0.9 & 1.4 & 0.17 & 0.8 & 3081 & 3081 & 0.03 \\
\hline CD (5\%) & 3.3 & 0.071 & 6.0 & 2.7 & 4.2 & 0.51 & NS & 9143 & 9143 & 0.09 \\
\hline \multicolumn{11}{|l|}{ Genotypes: } \\
\hline SPH-1835 & 178.2 & 4.08 & 90.6 & 51.5 & 52.8 & 6.71 & 40.2 & 100024 & 64933 & 2.85 \\
\hline SPH-1836 & 179.6 & 4.06 & 85.3 & 49.5 & 51.8 & 8.25 & 38.0 & 114421 & 79329 & 3.26 \\
\hline SPV-2348 & 130.0 & 2.83 & 85.4 & 51.3 & 35.9 & 8.00 & 39.1 & 84000 & 49669 & 2.42 \\
\hline SPV-2405 & 186.7 & 4.03 & 82.9 & 45.2 & 49.2 & 8.07 & 39.1 & 113250 & 78238 & 3.22 \\
\hline CSH-13R & 145.7 & 3.35 & 92.1 & 50.1 & 45.7 & 6.95 & 42.7 & 114274 & 79183 & 3.25 \\
\hline CSH-15R & 170.8 & 4.00 & 56.0 & 47.9 & 45.9 & 7.36 & 39.6 & 107852 & 78760 & 3.07 \\
\hline CSV-22R & 186.8 & 3.81 & 88.4 & 47.3 & 48.4 & 6.15 & 43.1 & 101174 & 66162 & 2.88 \\
\hline CSV-29R & 189.7 & 3.79 & 88.2 & 45.4 & 44.7 & 6.73 & 40.6 & 99938 & 64926 & 2.85 \\
\hline S.Em+ & 1.8 & 0.057 & 2.3 & 1.7 & 1.8 & 0.28 & 1.3 & 4032 & 4032 & 0.04 \\
\hline CD (5\%) & 5.4 & 0.176 & 6.6 & 5.1 & 5.4 & 0.83 & NS & 12076 & 12076 & 0.12 \\
\hline \multicolumn{11}{|l|}{ Interaction : } \\
\hline S.Em+ & 3.2 & 2.2 & 5.8 & 3.7 & 2.1 & 0.48 & 2.3 & 8715 & 8715 & 0.24 \\
\hline CD (5\%) & 9.4 & NS & 17.1 & 11.1 & 6.2 & 1.43 & 6.8 & 25562 & 25562 & 0.73 \\
\hline
\end{tabular}

Table.2 Interaction effects of advanced rabi sorghum genotypes and

Fertility levels on grain yield

\begin{tabular}{|c|c|c|c|c|c|c|c|c|c|}
\hline \multirow{2}{*}{$\begin{array}{l}\text { Fertility } \\
\text { levels }\end{array}$} & \multicolumn{8}{|c|}{ Genotypes } & \multirow[t]{2}{*}{ Mean } \\
\hline & $\begin{array}{l}\text { SPH- } \\
1835\end{array}$ & $\begin{array}{l}\text { SPH- } \\
1836\end{array}$ & $\begin{array}{l}\text { SPV- } \\
2348\end{array}$ & $\begin{array}{l}\text { SPV- } \\
2405\end{array}$ & $\begin{array}{c}\mathrm{CSH}^{-} \\
13 \mathrm{R}\end{array}$ & $\begin{array}{l}\mathrm{CSH} \\
-15 \mathrm{R}\end{array}$ & $\begin{array}{l}\text { CSV- } \\
22 \mathrm{R}\end{array}$ & $\begin{array}{l}\text { CSV- } \\
29 R\end{array}$ & \\
\hline $1.50 \% \mathrm{RDF}$ & 49.1 & 49.9 & 31.9 & 46.5 & 43.5 & 44.9 & 47.8 & 43.5 & 44.6 \\
\hline $2.75 \%$ RDF & 53.5 & 51.8 & 37.0 & 50.8 & 46.8 & 46.1 & 49.3 & 45.1 & 47.8 \\
\hline $\begin{array}{l}\text { 3.100\% } \\
\text { RDF }\end{array}$ & 55.7 & 53.8 & 38.7 & 50.4 & 46.8 & 46.9 & 50.2 & 45.6 & 50.2 \\
\hline Mean & 52.8 & 51.8 & 35.9 & 49.2 & 45.7 & 45.9 & 48.4 & 44.7 & \\
\hline & & & $\begin{array}{l}\text { S.Emt } \\
\text { D }(5 \%)\end{array}$ & $\begin{array}{l}2.1 \\
6.2\end{array}$ & & & & & \\
\hline
\end{tabular}


Among the hybrids, SPH-1835 recorded significantly higher grain yield $(52.8 \mathrm{q} / \mathrm{ha})$ compared to check hybrids and it was on par with SPH-1836. The increase in yield was to the tune of $1.9,13.4$ and $13.1 \%$ over SPH 1836, CSH-13R and CSH-15R respectively. Similarly among the varieties, SPV-2405 produced significantly higher grain yield (49.2 q/ ha) over SPV-2348 and check variety CSV-29R but on par with check variety CSV$22 \mathrm{R}$. The increase in grain yield was $27.0,1.6$ and $9.1 \%$ over SPV-2348, CSV-22R and CSV-29R respectively. The higher grain yield was mainly due to higher 100 -seed weight and grain yield/plant. While the fodder yield was significantly higher with hybrid SPH1836(8.25t/ha) over SPH-1835, check hybrids and varieties but was on par with new varieties SPV-2348 and SPV-2405.

The fodder yield was 18.7, 15.8, 10.7, 25.5 and $18.4 \%$ higher over SPH-1835, CSH-13R, CSH-15R, CSV-22R and CSV-29R respectively. The better performance of the new varieties and hybrids was due to influence of nutrients on protein synthesis, involvement in several physiological and metabolic processes in the plant system (Tisdale et al., 1990). Sumeriya et al., (2005) reported the similar results in kharif sorghum.

\section{Interaction effect}

The data on interaction effect of fertility levels and genotypes on grain yield revealed that the new hybrid SPH-1835 produced significantly higher grain yield of $55.7 \mathrm{q} / \mathrm{ha}$ at $100 \% \mathrm{RDF}$ as compared to rest of the treatment combinations except SPH-1836, SPV-2405, CSV-22R both at $100 \%$ RDF and $75 \%$ RDF (Table 2). These results were in conformity with the findings of Dashora et al., (2014) in kharif sorghum.

Thus based on the results, it may be inferred that application of $100 \%$ recommended doze of fertilizer of $50: 25 \mathrm{~kg} \mathrm{~N}$ and $\mathrm{P}_{2} \mathrm{O}_{5} /$ ha found optimum for both test hybrids and varieties of rabi sorghum for getting maximum yield and net returns.

\section{References}

Anonymous, (2015) www.Indiastat.com. Area and production, Directorate of Economics and Statistics, Department of Agriculture and Corporation report, New Delhi.

Bringer, K. A., Gore, S. R. and Banarjee, G., (1980). Waterlogging injury in sorghum seedlings and their kinetin affected rapid recovery. Plant Growth Regulation, 41: 23-31.

Dashora, L.N., Giriraj Gupta, Solanki, N. S., Mundra, S. L. and Kaushik, M. K., (2014). Response of Sorghum (Sorghum bicolor) genotypes to different fertility levels in South Rajasthan. Proceedings of National Symposium on Agricultural Diversification for Sustainable livelihood and Environmental Security, Nov. 18-20, 2014, Ludhiana, Punjab.

Gomez, K. A. and Gomez. A. A., (1984). Statistical Procedure for Agricultural Research, Edn 2. pp. 241-271. JohnWiley \& Sons, New York.

Khatik, R. L., Somani, L. L. and Mali, A. L., (1999). Response of promising sorghum genotypes to varying fertilizer levels in a Haplustalfs. Crop Research, 17: 30206.

Mali, A. L., Sumeriya, H. K. and Singh, I., (2000). Yield and monetary returns of sorghum cultivars under different fertility levels. Agriculture Science Digest, 20: 168-70.

Pushpendra Singh, Sumeriya, H. K., Vithal Sharma and Jain, D. K., (2006). Growth and yield of sorghum (Sorghum bicolor L.) genotypes as influenced by fertility levels, Research on Crops, 7(3): 683 686. 
Sumeriya, H. K., Singh, P. and Mali, A. L., (2005). Studies on the effect of fertility levels on growth and productivity of sorghum (Sorghum bicolor (L.) Moench). Crop Research, 30: 6-9.
Tisdale, S. L., Nelson, W. L. and Beaton, J. D., (1990). Soil Fertility and Fertilizer, $4^{\text {th }}$ Edn. MacMillan Publishing Company, New York.

\section{How to cite this article:}

Kubsad, V.S. 2018. Response of Rabi Sorghum Genotypes (Sorghum bicolor (L) Moench) to Different Fertility Levels under Rainfed Conditions. Int.J.Curr.Microbiol.App.Sci. 7(10): 32823286. doi: https://doi.org/10.20546/ijcmas.2018.710.380 